\title{
Height, branch-free bole length and bark thickness for six tree species used medicinally in South Africa
}

\author{
V.L. WILLIAMS, E.T.F. WITKOWSKI and K. BALKWILL
}

Williams, V.L., E.T.F. Witkowski and K. Balkwill. 2005. Heıght, branch-free bole length and bark thickness for six tree species used medicinally in South Africa. Koedoe 48(1): 57-65. Pretoria. ISSN 0075-6458.

Information on tree stem characterıstics and dimensions is sparse, especially information that would enhance conservation and trade monitorıng efforts for species where bark is harvested for medicinal use. Several tree stem characteristics were investigated during a study on the relationshıp between bark thickness and stem diameter, and this paper presents the mean height, branch-free bole length and wet and oven-dry bark thickness per stem diameter-class for six species. Additionally, prediction tables are constructed that allow bark thickness to be determined from diameter at breast height.

Key words: Acacıa xanthophloea, Albızıa adıanthifolıa, Balanites maughami, bark, diameter at breast height, Elaeodendron transvaalense, medicinal plants, Rhus chirindensis, Warburgia salutarts.

$V L$ Williams is: School of Antmal. Plant \& Environmental Sciences. Untversity of the Witwatersrand, Private Bag 3, Wits, 2050, South Africa (vivwill(a) planetac co za); E TF Witkowski, Restoration and Conservatıon Bıology Research Group, School of Animal, Plant \& Environmental Sciences, University of the Witwatersrand, PO Wits. 2050. South Africa; K Balkwill, School of Animal, Plant \& Environmental Sctences, University of the Witwatersrand, PO Wits, 2050, South Africa

\section{Introduction}

Woodland and forest species account for at least $73 \%$ of the income of traders in Johannesburg's traditional medicine street market (Williams 2004). Bark products account for the largest proportion $(52 \%)$ of the volume sold (Williams 2004). Despite the importance of bark in traditional medicine in South Africa, ethnobotanical literature about it is scant or inaccessible (Grace et al. 2002). Additionally, there is a lack of detailed information to empower conservation and trade monitoring efforts (Grace et al. 2002).

Uncontrolled bark harvesting for traditional medicine seriously impacts on forest ecosystems and species (Geldenhuys 2004), and harvesting is often highly selective for families, genera, species or tree size-classes based on particular bark qualities and secondary plant chemicals (Cunningham 2001). In an effort to monitor the availability of bark thickness size-classes in medicinal plant markets, as well as the impact of bark harvesting on tree populations, the authors explored the relationship between bark thickness and tree size for six species. In the absence of practical techniques to determine the age of trees, size can be used as a surrogate (van Wyk et al. 1996). Tree stems generally increase in girth as they get older, and diameters are therefore the most appropriate measure for grouping plants into size-classes. Bark thickness generally increases with diameter and stem age (Borger 1973). In some species, a straight-line relationship exists between bark thickness and stem diameter, owing to the persistence of the rhytidome (outer bark) and the resistance of bark to weathering (Borger 1973). In other species, however, the relationship is weak or curvilinear owing to the shedding of the bark to a greater or lesser extent (Borger 1973). 
The authors have already described the strength of the linear relationship between bark thickness and stem diameter (at $1.3 \mathrm{~m}$, diameter at breast height $(\mathrm{dbh})$ ) for six species, and constructed "tariff tables" to predict the dbh of the trees targeted by harvesters from the thickness and age of the bark found for sale in medicinal plant markets (Williams et al. in prep.). This paper presents the results of the mean wet and oven-dried bark thickness per size class of trees sampled, as well as the regressions and estimates of bark thickness at $1.3 \mathrm{~m}$ for trees of a specified diameter at breast height. Additionally, the mean height and branchfree bole length of individuals sampled from the six species are listed. The bark of the six tree species investigated are all used for traditional medicine and sold in the markets of
KwaZulu-Natal, Gauteng and Mpumalanga (Cunningham 1988; Williams et al. 2000; Botha 2001; Williams 2003). The information presented in this paper will serve as base-line autecological data for the species concerned, and is expected to be of value to researchers in the field of ethnobotany as well as to forest and resource managers/ecologists investigating population dynamics and the change in resource availability over time.

\section{Study sites and species}

Six species were sampled at fifteen woodland sites in three South African provinces between March and May 1998 (Table 1). Seven of the sites were on privately-owned

Table 1

Description of sample sites and the number of individuals sampled per species at each site

\begin{tabular}{|c|c|c|c|c|}
\hline Province & $\begin{array}{l}\text { Site } \\
\text { code }\end{array}$ & Area in province & $\begin{array}{l}\text { Ownership and } \\
\text { management regıme }\end{array}$ & Species sampled (No.) \\
\hline \multirow[t]{8}{*}{ Limpopo } & $\mathrm{L} 1$ & Western Soutpansberg & Prıvate game farm & $\begin{array}{l}R \text { chirındensis }(11) \\
W \text { salutarts }(27)\end{array}$ \\
\hline & $\mathrm{L} 2$ & Western Soutpansberg & Private farm & $\begin{array}{l}B \text { maughami }(17) \\
E \text { transvaalense }(1) \\
R \text { chirındensis }(9)\end{array}$ \\
\hline & L3 & Western Soutpansberg & Private farm & E transvaalense $(5)$ \\
\hline & L4 & Western Soutpansberg & Prıvate farm & $B$ maughamı $(13)$ \\
\hline & L5 & Nylstroom & Protected area & E transvaalense $(13)$ \\
\hline & L6 & Eastern Soutpansberg & State-owned forestry land & A adıanthifolıa (29) \\
\hline & L7 & Eastern Soutpansberg & State-owned forestry land & A adianthifolia (13) \\
\hline & L8 & Eastern Soutpansberg & State-owned forestry land & R. chirındensis (4) \\
\hline \multirow[t]{3}{*}{ Mpumalanga } & M1 & Nelspruit & Protected area & $\begin{array}{l}\text { A xanthophloea }(1) \\
B \text { maughamı }(2)\end{array}$ \\
\hline & M2 & South of Malalane & Private farm & $R$. chirindensts $(5)$ \\
\hline & M3 & South of Malalane & Private mine & $R$ chirındensis $(5)$ \\
\hline \multirow[t]{4}{*}{ KwaZulu-Natal } & $\mathrm{K} 1$ & Maputaland & Protected area & A xanthophloea (12) \\
\hline & $\mathrm{K} 2$ & Maputaland & Communal land & $\begin{array}{l}\text { A xanthophloea }(1) \\
B \text { maughamu }(3) \\
E \text { transvaalense }(6)\end{array}$ \\
\hline & $\mathrm{K} 3$ & Zululand & Protected area & $\begin{array}{l}\text { A xanthophloea }(1) \\
\text { A adıanthifolıa }(4) \\
B \text { maughamı }(1)\end{array}$ \\
\hline & $\mathrm{K} 4$ & Zululand & $\begin{array}{l}\text { Private company } \\
\text { protected area }\end{array}$ & $\begin{array}{l}\text { A xanthophloea (19) } \\
A \text { adıanthifolıa }(1) \\
B \text { maughamı }(3) \\
E \text { transvaalense (6) }\end{array}$ \\
\hline
\end{tabular}


Table 2

Descriptive data for the six tree species investigated

\begin{tabular}{|c|c|c|c|}
\hline Species and family & Size (Height) & Bark type a and description & $\begin{array}{l}\text { Other tree \& habitat } \\
\text { characteristics }\end{array}$ \\
\hline $\begin{array}{l}\text { Acacia xanthophloea } \\
\text { Benth. } \\
\text { MIMOSACEAE }\end{array}$ & $\begin{array}{l}\text { Medrum to large; aver- } \\
\text { age } 10-15 \mathrm{~m} \text {, up to } 30 \mathrm{~m}\end{array}$ & $\begin{array}{l}\text { Smooth/scaly/powdery bark: smooth, } \\
\text { exfoliating, greenish-yellow becom- } \\
\text { ing powdery yellow; as tree gets big- } \\
\text { ger, bark peels off in huge, thick } \\
\text { pieces }\end{array}$ & $\begin{array}{l}\text { Semi-deciduous; fast } \\
\text { growing } 1-1.5 \mathrm{~m} \text { in } \\
\text { height per year; } \\
\text { woodland }\end{array}$ \\
\hline $\begin{array}{l}\text { Albızıa adıanthifolıa } \\
\text { (Schumach.) } \\
\text { W.F.Wight } \\
\text { MIMOSACEAE }\end{array}$ & $\begin{array}{l}\text { Large to very large; } 10- \\
20 \mathrm{~m} \text {, up to }+25 \mathrm{~m}\end{array}$ & $\begin{array}{l}\text { Fissured bark: smooth and grey when } \\
\text { young, becoming rougher and form- } \\
\text { ing fine yellowish-brown blocks with } \\
\text { age }\end{array}$ & $\begin{array}{l}\text { Decıduous; interme- } \\
\text { diate growing } 0.6 \mathrm{~m} \\
\text { in heıght per year; } \\
\text { forest }\end{array}$ \\
\hline $\begin{array}{l}\text { Balamites maughamu } \\
\text { Sprague } \\
\text { BALANITACEAE }\end{array}$ & $\begin{array}{l}\text { Medium to large; } \\
8-20 \mathrm{~m} \text {, up to } 25 \mathrm{~m}\end{array}$ & $\begin{array}{l}\text { Tessellated bark. smooth and grey } \\
\text { when young, becoming rougher with } \\
\text { age }\end{array}$ & $\begin{array}{l}\text { Deciduous, older } \\
\text { trunks strongly fluted } \\
\text { and buttressed; slow } \\
\text { growing; woodland }\end{array}$ \\
\hline $\begin{array}{l}\text { Elaeodendron trans- } \\
\text { vaalense (Burtt Davy) } \\
\text { R.H.Archer } \\
\text { CELASTKACEAE }\end{array}$ & $\begin{array}{l}\text { Shrub or small to } \\
\text { medium multi-branched } \\
\text { tree, } 4-6 \mathrm{~m} \text {, up to } \\
10-15 \mathrm{~m}\end{array}$ & $\begin{array}{l}\text { Patchy bark: farrly smooth and pale } \\
\text { grey when young, becoming darker, } \\
\text { "blocky' and deeply fissured with } \\
\text { age; rhytidome exfoliates in thin } \\
\text { scales }\end{array}$ & $\begin{array}{l}\text { Semi-deciduous; } \\
\text { slow growing } 0.5 \mathrm{~m} \\
\text { in height per year: } \\
\text { woodland }\end{array}$ \\
\hline $\begin{array}{l}\text { Rhus chirindensts } \\
\text { Baker } \mathrm{f} \text {. } \\
\text { ANACARDIACEAE }\end{array}$ & $\begin{array}{l}\text { Shrub or small to large } \\
\text { tree: } 3-4 \mathrm{~m} \text {, occasionally } \\
6-10 \mathrm{~m} \text {; exceptional } \\
\text { specimens up to } 20 \mathrm{~m}\end{array}$ & $\begin{array}{l}\text { Tessellated bark: smooth and dark } \\
\text { grey or brown when young, becom- } \\
\text { ing dark and cracked with age }\end{array}$ & $\begin{array}{l}\text { Semı-deciduous: fast } \\
\text { growing up to } 1 \mathrm{~m} \text { in } \\
\text { height per year; } \\
\text { forest and woodland }\end{array}$ \\
\hline $\begin{array}{l}\text { Warburgia salutarts } \\
\text { (Bertol.f.) Chıov. } \\
\text { CANELLACEAE. }\end{array}$ & $\begin{array}{l}\text { Shrub or medium-sized } \\
\text { to large: usually } 5-10 \mathrm{~m} \text {, } \\
\text { up to } 20 \mathrm{~m}\end{array}$ & $\begin{array}{l}\text { Fissured bark: slightly rough, mottled } \\
\text { dark brown and grey when young, } \\
\text { becoming courser and more fissured } \\
\text { with age, lenticellate }\end{array}$ & $\begin{array}{l}\text { Evergreen aromatic; } \\
\text { farly slow-growing, } \\
\text { but can be as much } \\
\text { as } 0.9 \mathrm{~m} \text { in height } \\
\text { per year in warm, } \\
\text { frost-free areas; for- } \\
\text { est and woodland }\end{array}$ \\
\hline
\end{tabular}

Sources: Archer \& van Wyk (1998); Carr (1994); Grant \& Thomas (1997, 1998, 2000); Hankey \& Stern (2002); Immelman et al (1973); Mander et al (1995); Palgrave (1977); Pooley (1993); Schmidt et al (2002); Scott-Shaw (1999); Turner (2003); Van Wyk (1974); Van Wyk \& Van Wyk (1997); Van Wyk et al (1997); Venter \& Venter (1996).

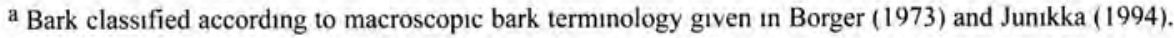

land, four were in protected areas, three on state-owned forestry land and one on communal land. The species were previously selected to represent various risk categories for over-exploitation by the medicinal plant trade (V.L. Williams unpubl. data). In high demand and at high risk are Warburgia salutaris (Bertol.f.) Chiov. and Elaeodendron transvaalense (Burtt Davy) R.H. Archer [formerly known as Cassine transvaalensis (Burtt Davy) Codd]. Also widely used but at a lower risk due to lower levels of exploitation are Albizia adianthifolia (Schumach.) W.F.Wight, Balanites maughamii Sprague and Acacia xanthophloea Benth. Rhus chirindensis Baker $\mathrm{f}$. tends not to be as widely utilised as the other species, but in some areas significant damage to populations has been reported (Geldenhuys 2004). The species range in size, growth rate, bark type and habitat (Table 2). 


\section{Field methods and data analysis}

At each sample site, individuals were selected from various representatıve size-classes based on the stem diameter at breast height (dbh, $1.3 \mathrm{~m}$ above ground). A minımum of five and maxımum of ten trees was sampled per diameter-class per species, although specimens in the $\geq 40 \mathrm{~cm}$ size-classes were sometımes more difficult to find, and hence 2-4 trees were often sampled in this class (except for Albizia, where trees larger than $60 \mathrm{~cm}$ dbh could have been sampled). Stem diameter-classes for Acacia, Albızıa, Balantes and Elaeodendron were in increments of $10 \mathrm{~cm}$, startıng at $10 \mathrm{~cm}$ and ending at $50 \mathrm{~cm}, 60 \mathrm{~cm}$, $60 \mathrm{~cm}$ and $50 \mathrm{~cm}$ respectively. Diameter-classes for Rhus and Warburgla were in increments of $5 \mathrm{~cm}$, startıng at $5 \mathrm{~cm}$ and ending at $35 \mathrm{~cm}$ and $30 \mathrm{~cm}$ respectively due to the prevalence of individuals in this size range.

Varıous aspects of the tree stem profile were measured: 1) diameter of the stem at five height intervals $(0.5 \mathrm{~m}, 1.0 \mathrm{~m}, 1.3 \mathrm{~m}, 1.5 \mathrm{~m}$ and $2.0 \mathrm{~m})$; 2) approximate tree height; and 3) branch-free bole length. A diameter tape was used to measure the diameter of the stem directly from the circumference measurement. Vertical height and branch-free bole length were directly estımated using a two-metrehigh pole that was marked in $0.5 \mathrm{~m}$ intervals. The number of pole lengths was then counted by eye to estımate height and length. Bark samples were removed from the stem using a $50 \mathrm{~mm}$ diameter hole-saw attached to a hand drill brace. Bark thickness of the samples was measured on site using a digital Vernier calliper (accuracy: $0.01 \mathrm{~mm}$ ), and mass was measured using a portable digital scale (accuracy: $5 \mathrm{~g}$ ). The bark samples were placed into a phytotron chamber at the University of the Witwatersrand to dry out, and thickness and mass measure- ments (this tıme with an electronic balance accurate to $0.001 \mathrm{~g}$ ) were recorded weekly for each sample. The temperature and relative humidity $(\mathrm{RH})$ in the chamber were set to mimic mean day and night summer conditions (September-March) in Johannesburg, namely: day $\mathrm{T}^{\circ}=20^{\circ} \mathrm{C}$; night $\mathrm{T}^{\circ}=16^{\circ} \mathrm{C}$; day $\mathrm{RH}=59 \%$; night $\mathrm{RH}=66 \%$. Twelve weeks after the samples were harvested, they were oven-dried at $80^{\circ} \mathrm{C}$ for four days. Regressions between dbh, bark thickness and mass were calculated using STATISTICA 6 and Excel 2000. Refer to Williams et al (in prep.) for detalled information on the methods and regression analysis between bark thıckness and stem diameter, as well as the estımation of tree dbh from bark thickness and age (tıme after harvestıng) records.

\section{Results and discussion}

Between the six species, 1026 bark samples were removed from 207 individual stems. The largest tree encountered was a mature $W$. salutaris located on a private farm in the Limpopo Province which had a dbh $>68 \mathrm{~cm}$ (also the level that branching occurred, which could have rendered the dbh reading inaccurate) (Table 3). In terms of the availability of individuals within the various sizeclasses that could be sampled, most prevalent were stems between $10-39 \mathrm{~cm}$ dbh for A. xanthophloea, A. adianthifolia, B. maughamii and E. transvaalense (Table 4). Stems with $\mathrm{dbh}<10 \mathrm{~cm}$ were not measured for these four species. Mature trees with stems of $\mathrm{dbh}>40 \mathrm{~cm}$ were not as common (except

Table 3

Tree dimensions for the six study species

\begin{tabular}{|c|c|c|c|c|c|c|}
\hline \multirow[t]{2}{*}{ Species } & \multirow[t]{2}{*}{$\mathrm{N}$} & \multicolumn{2}{|c|}{ Tree height (m) } & \multicolumn{2}{|c|}{ Branch-free bole length $(\mathrm{m})$} & \multirow[t]{2}{*}{ LD } \\
\hline & & Mean \pm SD & Min; Max & Mean \pm SD & Min; Max & \\
\hline Acacia xanthophloea & 33 & $10.2 \pm 2.1$ & $6.0 ; 15.0$ & $4.3 \pm 2.5$ & $1.5 ; 10.0$ & $47.4 \mathrm{~cm}(\mathrm{~K} 4)$ \\
\hline Albızıa adıanthıfolıa & 46 & $9.9 \pm 2.1$ & $6.0 ; 14.0$ & $4.6 \pm 2.5$ & $0.5 ; 11.0$ & $59.9 \mathrm{~cm}(\mathrm{~L} 6)$ \\
\hline Balanites maughamu & 38 & $7.9 \pm 2.2$ & $4.0 ; 12.0$ & $2.9 \pm 1.4$ & $0.9 ; 7.0$ & $59.2 \mathrm{~cm}(\mathrm{~K} 4)$ \\
\hline $\begin{array}{l}\text { Elaeodendron } \\
\text { transvaalense }\end{array}$ & 30 & $5.1 \pm 1.4$ & $3.5 ; 8.0$ & $2.1 \pm 0.8$ & $1.0 ; 4.5$ & $48.3 \mathrm{~cm}$ (L5) \\
\hline Rhus chirındensis & 33 & $7.7 \pm 2.6$ & $4.0 ; 14.0$ & $3.5 \pm 1.8$ & $1.7 ; 8.0$ & $31.2 \mathrm{~cm}(\mathrm{~L} 8)$ \\
\hline Warburgıa salutarls & 27 & $8.1 \pm 2.9$ & $3.5 ; 14.0$ & $2.8 \pm 1.3$ & $1.2 ; 6.0$ & $>68 \mathrm{~cm}(\mathrm{~L} 1)$ \\
\hline
\end{tabular}

$\mathrm{LD}=$ Largest diameter recorded at $1.3 \mathrm{~m}(\mathrm{dbh})$ (sıte abbreviatıon, see Table 1$)$ 
for Albizia, where individuals between 50$59 \mathrm{~cm}$ were abundant). For $R$. chirindensis and $W$. salutaris, however, the most prevalent size-classes were between $5-24 \mathrm{~cm}$ and $5-19 \mathrm{~cm}$ dbh respectively. Individuals larger than $25 \mathrm{~cm}$ were infrequently encountered (Table 4), although a revisit to two of the sites in 2004 located populations with individuals in the $30-39 \mathrm{~cm}$ class that had previously not been observed. The data for $A$. xanthophloea and $W$. salutaris correspond with population structure data obtained by Botha et al. $(2002,2004)$ for these species in the Lowveld, South Africa.

The minimum and maximum heights of the trees are consistent with the size range of the species in the wild (Tables $2 \& 3$ ). The mean heights of $A$. xanthophloea, $A$. adianthifolia and $B$. maughamii indicated that the individuals sampled tended to be at the lower end of the size range, whereas $E$. transvaalense, $R$. chirindensis and $W$. salutaris were at the larger end of the range. In the Umzimkulu forests of the Eastern Cape, the stem diameters of $R$. chirindensis are much larger than recorded in this study (C.J. Geldenhuys pers. comm.). The mean branch-free bole length indicated that on average, branching commences above $2 \mathrm{~m}$ - the level to which bark is assumed to be within reach for harvesting from a standing tree.

The mean wet bark thicknesses of the individuals sampled are shown in Table 4 , as well as the minimum and maximum thickness measured. Wet-bark thickness was measured on the day the samples were removed from the trees. The results show a positive increase in bark thickness with stem diameter, except for $A$. xanthophloea. There is a weak relationship between bark thickness and dbh in this species (Table 5) because of the tendency for the bark to be shed in large strips and hence no age-related accumulation of the outer bark (Williams et al. in prep.).

The oven-dry bark thickness is also presented (Table 4) because the moisture content of the bark generally varies seasonally and between sites (Cunningham 2001), hence
Table 4

Mean wet and oven-dry bark thickness of the samples per size-class per species

\begin{tabular}{llllll}
\hline $\begin{array}{l}\text { Size-class } \\
(\mathrm{dbh})(\mathrm{cm})\end{array}$ & $\begin{array}{l}\text { Mean } \\
(\mathrm{mm})\end{array}$ & SD & $\begin{array}{c}\text { Mın } \\
(\mathrm{mm})\end{array}$ & $\begin{array}{c}\text { Max } \\
(\mathrm{mm})\end{array}$ & $N^{1}$ \\
\hline
\end{tabular}

Acacta xamthophloea

a) Wet bark thickness

$\begin{array}{llllll}10-19 & 8.22 & 127 & 665 & 1056 & 10 \\ 20-29 & 862 & 309 & 396 & 1305 & 10 \\ 30-39 & 883 & 274 & 599 & 1318 & 10 \\ 40-49 & 7.02 & 1.6 & 5.89 & 815 & 2\end{array}$

b) Oven-dry bark thickness [mean decrease in thickness $505 \%=4.2 \%$ (SD)]

\begin{tabular}{llllll}
$10-19$ & 387 & 0.60 & 3.07 & 4.68 & 10 \\
$20-29$ & 434 & 171 & 1.83 & 7.11 & 10 \\
$30-39$ & 460 & 1.58 & 3.05 & 7.50 & 10 \\
$40-49$ & 6.24 & 534 & 2.54 & 12.36 & 3 \\
\hline
\end{tabular}

Albizıa adianthifolia

a) Wet bark thickness

$\begin{array}{cccccc}10-19 & 583 & 199 & 207 & 9.77 & 10 \\ 20-29 & 8.75 & 2.54 & 6.55 & 1566 & 11 \\ 30-39 & 1092 & 1.01 & 8.99 & 12.05 & 10 \\ 40-49 & 12.25 & 265 & 769 & 15.06 & 7 \\ 50-59 & 1355 & 1.27 & 1173 & 1518 & 8\end{array}$

b) Oven-dry bark thickness [mean decrease in thickness $523 \% \pm 10.5 \%$ (SD)]

$\begin{array}{llllll}10-19 & 2.63 & 084 & 105 & 416 & 10 \\ 20-29 & 3.84 & 0.86 & 273 & 5.70 & 10 \\ 30-39 & 5.40 & 110 & 3.45 & 6.68 & 10 \\ 40-49 & 6.20 & 1.18 & 4.08 & 7.67 & 7 \\ 50-59 & 708 & 133 & 520 & 8.90 & 9\end{array}$

Balanites maughamu

a) Wet bark thickness

$\begin{array}{llllll}10-19 & 5.73 & 2.08 & 176 & 10.38 & 13 \\ 20-29 & 804 & 2.57 & 4.37 & 12.42 & 10 \\ 30-39 & 8.80 & 2.80 & 378 & 12.52 & 8 \\ 40-49 & 9.69 & 187 & 7.26 & 11.67 & 4 \\ 50-59 & 991 & 3.33 & 4.95 & 12.1 & 4\end{array}$

b) Oven-dry bark thickness [mean decrease in thickness $24.0 \% \pm 83 \%$ (SD)]

\begin{tabular}{llllll}
$10-19$ & 5.31 & 162 & 4.05 & 8.74 & 7 \\
$20-29$ & 6.26 & 2.41 & 3.33 & 989 & 10 \\
$30-39$ & 6.88 & 2.27 & 2.32 & 932 & 8 \\
$40-49$ & 6.18 & 1.09 & 5.24 & 7.37 & 3 \\
$50-59$ & 7.87 & 2.77 & 4.07 & 10.59 & 4 \\
\hline
\end{tabular}

1 The discrepancies between $\mathrm{N}$ (wet bark thickness) and $N$ (oven-dry bark thickness) result from some of the bark samples breakıng and not being measurable after 13 weeks. Additionally, the discrepancy in $\mathrm{N}$ for wet and oven-dry thickness for the $40-49 \mathrm{~cm}$ and $50-59$ sizeclasses of $A$ xanthophloea and $A$ adianthifolia respectıvely are the result of one bark sample not being measured on-site for wet bark thickness, but being measured every week thereafter until oven-dried. 
Table 4 (contınued)

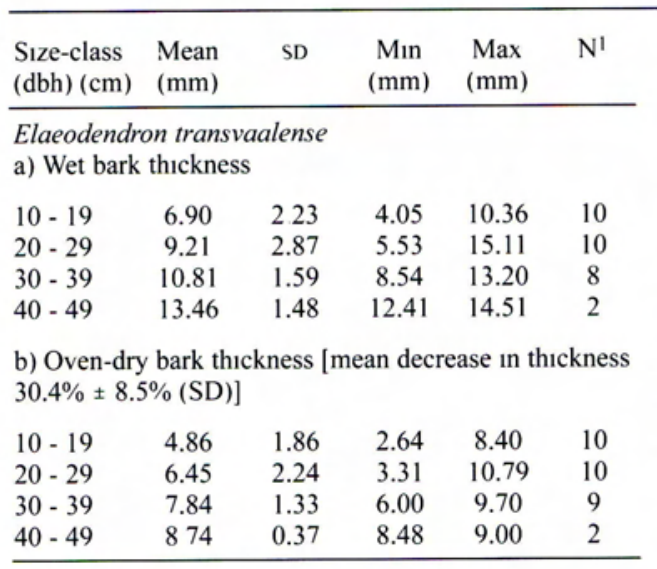

Rhus chirindensis

a) Wet bark thickness

$\begin{array}{lccccc}5-9 & 3.19 & 0.46 & 2.56 & 3.98 & 10 \\ 10-14 & 5.24 & 1.82 & 2.73 & 7.38 & 7 \\ 15-19 & 5.65 & 1.31 & 4.81 & 7.87 & 5 \\ 20-24 & 7.31 & 1.59 & 4.56 & 10.06 & 8 \\ 25-29 & 10.79 & 1.18 & 9.95 & 11.62 & 2 \\ (31.2) & (7.36)^{\mathrm{a}} & & & & 1\end{array}$

a Only one bark sample for the size class hence figure is the actual, not mean, value

b) Oven-dry bark thickness [mean decrease in thickness $50.7 \% \pm 9.7 \%(\mathrm{SD})]$

$\begin{array}{llllll}5-9 & 1.59 & 0.25 & 1.14 & 1.99 & 9 \\ 10-14 & 2.24 & 0.90 & 1.22 & 3.89 & 7 \\ 15-19 & 3.12 & 1.06 & 2.32 & 4.94 & 5 \\ 20-24 & 3.72 & 1.33 & 2.30 & 5.87 & 7 \\ 25-29 & 5.23 & 0.55 & 4.84 & 5.62 & 2 \\ 30-34 & (-)^{b} & & & & -\end{array}$

b Bark sample broke up and could not be oven dried

Warburgı salutarts

a) Wet bark thickness

$\begin{array}{lccccc}5-9 & 4.64 & 0.99 & 3.44 & 6.38 & 11 \\ 10-14 & 5.41 & 0.45 & 4.66 & 5.86 & 7 \\ 15-19 & 6.81 & 2.01 & 5.36 & 11.26 & 6 \\ 20-24 & 9.91 & 0.01 & 9.90 & 9.92 & 2 \\ 25-29 & (12.68)^{\mathrm{c}} & & & & 1 \\ (60-69) & (\approx 150)^{\mathrm{d}} & & & & \end{array}$

c Only one bark sample for the size class hence figure is the actual, not mean, value

d Sample not taken at dbh because of branchıng. Estımate based on bark thıcknesses at 1.0 and $1.5 \mathrm{~m}$

b) Oven-dry bark thickness [mean decrease in thıckness $49.3 \% \pm 7.6 \%$ (SD)]

$\begin{array}{llllll}5-9 & 2.39 & 0.79 & 1.39 & 3.56 & 10 \\ 10-14 & 3.01 & 0.35 & 2.47 & 3.52 & 7 \\ 15-19 & 3.70 & 1.55 & 1.99 & 6.22 & 5\end{array}$

\begin{tabular}{lccccc}
$\begin{array}{l}\text { Size-class } \\
(\mathrm{dbh})(\mathrm{cm})\end{array}$ & $\begin{array}{c}\text { Mean } \\
(\mathrm{mm})\end{array}$ & SD & $\begin{array}{c}\text { Mın } \\
(\mathrm{mm})\end{array}$ & $\begin{array}{c}\text { Max } \\
(\mathrm{mm})\end{array}$ & $\mathrm{N}^{1}$ \\
\hline $20-24$ & $\begin{array}{c}4.76 \\
25-29\end{array}$ & 0.45 & 4.44 & 5.07 & 2 \\
$(60-68)$ & & & & 1 \\
\hline
\end{tabular}

1 The discrepancies between $\mathrm{N}$ (wet bark thickness) and $\mathrm{N}$ (oven-dry bark thickness) result from some of the bark samples breakıng and not beıng measurable after 13 weeks. Additionally, the discrepancy in $\mathrm{N}$ for wet and oven-dry thickness for the 30-39 size-class of $E$ transvaalense is the result of one bark sample not being measured on site for wet bark thickness, but being measured every week thereafter untıl oven-dried.

the measurement provides a standard for comparison with other samples. The increase in mean bark thickness with increased dbh size-class is still evident. The mean percentage decrease in wet- and ovendried bark thickness is indicative of the amount of moisture stored and the density of the bark. In general, bark of the targeted species lose $50 \%$ of their original thickness after oven drying, except for B. maughamii and $E$. transvaalense, which lose a quarter and a third of their original thickness respectively (Table 4).

The equations and strength of the linear relationship between wet bark thickness and $\mathrm{dbh}$ are shown in Table 5. These relationships are described in more detail in Williams et al. (in prep.), especially in relation to bark type and shedding. Here, however, we present tables derived from the regressions that predict the wet bark thickness and prediction limits at the specified dbh for each tree species (Table 5). These results represent bark thicknesses that would likely be encountered at $1.3 \mathrm{~m}$ trunk height during field measurements of tree populations. For species such as $\mathrm{A}$. adianthifolia and $W$. salutaris, there is a strong positive correlation between bark thickness and tree size owing to the persistent nature of the bark on the stem (Williams et al.in prep.). The relationship is weaker in 
Table 5

Predicted bark thickness ( $x \pm 95 \%$ prediction range) from dbh. Predictions are for bark thickness on the day of sampling No prediction table was constructed for Acacia xanthophloea because there was no significant linear relationship between bark thickness and dbh. The regression equations, $r^{2}$ and $p$ for the species are as follows.

where $y=$ bark thickness $(\mathrm{mm})$ and $x=d b h(\mathrm{~cm})$ Acacia xanthophloea $y=79869+00065 x, r^{2}=0005$. $p=0.91$ Albızıa adianthıfolıa: $y=21853+02146 x, r^{2}=0802, p<00001$ Balanites maughamı $y=31844+$ 0 1601x, $r^{2}=0$ 61; $p<00001$ Elaeodendron transvaalense $y=36746+0202 x, r^{2}=0$ 503, $p=0$ 00002. Rhus chirındensis $y=11473+0301 x, r^{2}=0677, p<00001$ Warburgia salutaris $y=1.5087+03791 x, r^{2}=0882$. $p<00001$

\begin{tabular}{|c|c|c|c|c|c|c|c|c|c|c|}
\hline \multirow{2}{*}{$\begin{array}{l}\text { Spp. } \\
\begin{array}{l}\text { DBH } \\
(\mathrm{cm})\end{array}\end{array}$} & \multicolumn{2}{|c|}{$\begin{array}{c}\text { Albizia } \\
\text { adıanthıfolıa }\end{array}$} & \multicolumn{2}{|c|}{$\begin{array}{l}\text { Balanutes } \\
\text { maughamu }\end{array}$} & \multicolumn{2}{|c|}{$\begin{array}{l}\text { Elaeodendron } \\
\text { transvaalense }\end{array}$} & \multicolumn{2}{|c|}{$\begin{array}{c}\text { Rhus } \\
\text { chirindensis }\end{array}$} & \multicolumn{2}{|c|}{$\begin{array}{l}\text { Warburgia } \\
\text { salutarts }\end{array}$} \\
\hline & $\begin{array}{l}\text { Predicted } \\
\text { bark } \\
\text { thickness } \\
(\mathrm{mm})\end{array}$ & $\begin{array}{l} \pm 95 \% \\
\text { prediction } \\
\text { range } \\
(\mathrm{mm})\end{array}$ & $\begin{array}{l}\text { Predicted } \\
\text { bark } \\
\text { thickness } \\
(\mathrm{mm})\end{array}$ & $\begin{array}{c} \pm 95 \% \\
\text { prediction } \\
\text { range } \\
(\mathrm{mm})\end{array}$ & $\begin{array}{l}\text { Predicted } \\
\text { bark } \\
\text { thickness } \\
(\mathrm{mm})\end{array}$ & $\begin{array}{c} \pm 95 \% \\
\text { prediction } \\
\text { range } \\
(\mathrm{mm})\end{array}$ & $\begin{array}{l}\text { Predicted } \\
\text { bark } \\
\text { thickness } \\
(\mathrm{mm})\end{array}$ & $\begin{array}{l} \pm 95 \% \\
\text { prediction } \\
\text { range } \\
(\mathrm{mm})\end{array}$ & $\begin{array}{l}\text { Predıcted } \\
\text { bark } \\
\text { thıckness } \\
(\mathrm{mm})\end{array}$ & $\begin{array}{c} \pm 95 \% \text { pre- } \\
\text { diction } \\
\text { range } \\
(\mathrm{mm})\end{array}$ \\
\hline 3 & 3.4 & $<1 ; 6.7$ & 3.7 & $2.4 ; 4.9$ & 4.3 & $<1 ; 8.6$ & 2.1 & $<1 ; 5.1$ & 2.6 & $0.9 ; 4.4$ \\
\hline 4 & 3.7 & $<1 ; 6.9$ & 3.8 & $2.6 ; 5.1$ & 4.5 & $<1 ; 8.7$ & 2.4 & $<\mathrm{I} ; 5.4$ & 3.0 & $1.3 ; 4.7$ \\
\hline 5 & 3.9 & $<1 ; 7.1$ & 4.0 & $2.8 ; 5.2$ & 4.7 & $<1 ; 8.9$ & 2.7 & $<1 ; 5.7$ & 3.4 & $1.7 ; 5.1$ \\
\hline 6 & $4 . I$ & $<1 ; 7.3$ & 4.1 & $3.0 ; 5.3$ & 4.9 & $<1 ; 9.1$ & 3.0 & $<1 ; 6.0$ & 3.8 & $2.1 ; 4.6$ \\
\hline 7 & 4.3 & $1.1 ; 7.5$ & 4.3 & $3.2: 5.4$ & 5.1 & $<1 ; 9.2$ & 3.3 & $<1 ; 6.2$ & 4.2 & $2.5 ; 5.9$ \\
\hline 8 & 4.5 & $1.3 ; 7.7$ & 4.5 & $3.4 ; 5.6$ & 5.3 & $1.2 ; 9.4$ & 3.6 & $<1 ; 6.5$ & 4.5 & $2.9 ; 6.2$ \\
\hline 9 & 4.7 & $1.6 ; 7.9$ & 4.6 & $3.6 ; 5.7$ & 5.5 & $1.4 ; 9.6$ & 3.9 & $<1 ; 6.8$ & 4.9 & $3.3 ; 6.6$ \\
\hline 10 & 5.0 & $1.8 ; 8.1$ & 4.8. & $3.8 ; 5.8$ & 5.7 & $1.6 ; 9.8$ & 4.2 & $1.2 ; 7.1$ & 5.3 & $3.6 ; 7.0$ \\
\hline 11 & 5.2 & $2.0 ; 8.3$ & 4.9 & $4.0,5.9$ & 5.9 & $1.9 ; 9.9$ & 4.5 & $1.5: 7.4$ & 5.7 & $4.0 ; 7.3$ \\
\hline 12 & 5.4 & $2.2 ; 8.5$ & 5.1 & $4.2 ; 6.1$ & 6.1 & $2.1 ; 10.1$ & 4.8 & $1.8 ; 7.7$ & 6.1 & $4.4 ; 7.7$ \\
\hline 13 & 5.6 & $2.5 ; 8.7$ & 5.3 & $4.4 ; 6.2$ & 6.3 & $2.3 ; 10.3$ & 5.1 & $2.1 ; 8.0$ & 6.4 & $4.8 ; 8.1$ \\
\hline 14 & 5.8 & $2.7 ; 8.9$ & 5.4 & $4.5 ; 6.3$ & 6.5 & $2.5 ; 10.5$ & 5.4 & $2.4 ; 8.3$ & 6.8 & $5.2 ; 8.5$ \\
\hline 15 & 6.0 & $2.9 ; 9.2$ & 5.6 & $4.7 ; 6.4$ & 6.7 & $2.7 ; 10.7$ & 5.7 & $2.7 ; 8.6$ & 7.2 & $5.5 ; 8.9$ \\
\hline 16 & 6.2 & $3.1 ; 9.4$ & 5.7 & $5.0 ; 6.6$ & 6.9 & $3.0 ; 10.9$ & 6.0 & $3.0 ; 8.9$ & 7.6 & $5.9 ; 9.2$ \\
\hline 17 & 6.5 & $3.3 ; 9.6$ & 5.9 & $5.1 ; 6.7$ & 7.1 & $3.2: 11.0$ & 6.3 & $3.3 ; 9.2$ & 8.0 & $6.3 ; 9.6$ \\
\hline 18 & 6.7 & $3.6 ; 9.8$ & 6.1 & $5.3 ; 6.8$ & 7.3 & $3.4 ; 11.2$ & 6.6 & $3.6 ; 9.5$ & 8.3 & $6.6 ; 10.0$ \\
\hline 19 & 6.9 & $3.8 ; 10.0$ & 6.2 & $5.5 ; 7.0$ & 7.5 & $3.6 ; 11.4$ & 6.9 & $3.9 ; 9.8$ & 8.7 & $7.0 ; 10.4$ \\
\hline 20 & 7.1. & $4.0 ; 10.2$ & 6.4 & $5.7,7.1$ & .7.7. & $3.8 ; 11.6$ & ...2. & $4.2 ; 10.1$ & 9.1. & $7.4 ; 10.8$ \\
\hline 21 & 7.3 & $4.2 ; 10.4$ & 6.5 & $5.9 ; 7.2$ & 7.9 & $4.0 ; 11.8$ & 7.5 & $4.5 ; 10.4$ & 9.5 & $7.7 ; 11.2$ \\
\hline 22 & 7.5 & $4.4 ; 10.6$ & 6.7 & $6.1: 7.4$ & 8.1 & $4.2 ; 12.0$ & 7.8 & $4.8: 10.7$ & 9.9 & $8.1: 11.6$ \\
\hline 23 & 7.8 & $4.7 ; 10.8$ & 6.9 & $6.2 ; 7.5$ & 8.3 & $4.4 ; 12.2$ & 8.1 & $5.1 ; 11.1$ & 10.2 & $8.4 ; 12.0$ \\
\hline 24 & 8.0 & $4.9 ; 11.0$ & 7.0 & $6.4 ; 7,7$ & 8.5 & $4.6 ; 12.4$ & 8.4 & $5.4 ; 11.4$ & 10.6 & $8.8 ; 12.4$ \\
\hline 25 & 8.2 & $5.1 ; 11.3$ & 7.2 & $6.6: 7.8$ & 8.7 & $4.8 ; 12.6$ & 8.7 & $5.6 ; 11.7$ & 11.0 & $9.2 ; 12.8$ \\
\hline 26 & 8.4 & $5.3 ; 11.5$ & 7.3 & $6.7 ; 7.9$ & 8.9 & $5.0 ; 12.8$ & 9.0 & $5.9 ; 12.0$ & 11.4 & $9.5 ; 13.2$ \\
\hline 27 & 8.6 & $5.5 ; 11.7$ & 7.5 & $6.9 ; 8.1$ & 9.1 & $5.2 ; 13.0$ & 9.3 & $6.2 ; 12.4$ & 11.7 & $9.9 ; 13.6$ \\
\hline 28 & 8.8 & $5.8 ; 11.9$ & 7.7 & $7.1 ; 8.3$ & 9.3 & $5.4 ; 13.2$ & 9.6 & $6.5: 12.7$ & 12.1 & $10.2 ; 14.0$ \\
\hline 29 & 9.0 & $6.0 ; 12.1$ & 7.8 & 7,$2 ; 8.4$ & 9.5 & $5.6 ; 13.4$ & 9.9 & $6.7 ; 13.0$ & 12.5 & $10.6 ; 14.4$ \\
\hline 30 & 9.3 & $6.2 ; 12.3$ & 8.0 & $7.4: 8.6$ & 9.7 & $5.8: 13.6$ & 10.2 & $7.0 ; 13.3$ & 12.9 & $10.9 ; 14.9$ \\
\hline 35 & 10.3 & $7.3 ; 13.4$ & 8.8 & $8.1 ; 9.5$ & 10.7 & $6.8 ; 14.7$ & 11.7 & $8.3 ; 15.0$ & 14.8 & $12.6 ; 16.9$ \\
\hline 40 & 11.4 & $8.3 \div 14.5$ & 9.6 & $8.8 ; 10.4$ & 11.8 & $7.7 ; 15.8$ & 13.2 & $9.6 ; 16.7$ & 16.7 & $14.3 ; 19.0$ \\
\hline 45 & 12.5 & $9.4 ; 15.6$ & 10.4 & $9.4 ; 11.4$ & 12.8 & $8.6 ; 17.0$ & 14.7 & $10.9 ; 18.5$ & 18.6 & $16.0 ; 21.1$ \\
\hline 50 & 13.5 & $10.4 ; 16.7$ & 11.2 & $10.0 ; 12.6$ & 13.8 & $9.4: 18.1$ & 16.2 & $12.1 ; 20.3$ & 20.5 & $17.7 ; 23.3$ \\
\hline 55 & 14.6 & $11.5 ; 17.8$ & 12.0 & $10.6 ; 13.4$ & & & & & 22.4 & $19.3 ; 25.4$ \\
\hline 60 & 15.7 & $12.5 ; 18.9$ & 12.8 & $11.2 ; 14.4$ & & & & & 24.3 & $20.9 ; 27.6$ \\
\hline 65 & & & & & & & & & 26.2 & $22.6 ; 29.7$ \\
\hline 70 & & & & & & & & & 28.1 & $24.2 ; 31.9$ \\
\hline
\end{tabular}


E. transvaalense due to the irregular shedding of the bark on the bole, and hence the actual thickness of the bark cannot be predicted with as much confidence as for the other species.

The present study aims to provide information that will facilitate conservation and trade monitoring efforts with respect to tree population studies and the harvesting of bark for the medicinal plant trade and domestic use. Commercial bark harvesters tend to select individuals in the larger size-classes to maximise their returns (Botha et al. 2001), and the tables are a useful guide to the sizes of trees from which bark traded in a medicinal plant market is likely to have been harvested. Additionally, the tables serve as a guide for quantitative assessments of bark thickness in tree populations if the actual bark thickness cannot be measured on site but the dbh can.

\section{Acknowledgements}

Thanks are due to Megan Whelan for field assistance. We are grateful to the NRF and the Endangered Wildlıfe Trust's Eddie Young Memorial Bursary for funding. We thank Coert Geldenhuys and Wessel Vermeulen for providing valuable comments on a previous draft.

\section{References}

ARCHER, R.H. \& A.E. VAN WYK. 1998. A taxonomic revision of Elaeodendron Jacq. (Cassinoldeae: (elastraceae) in Africa. South African Journal of Botany 64(2): 93-109.

Borger, G.A. 1973. Development and shedding of bark. Pp 205-236. In: KozlowSKI, T.T. (ed.). Shedding of plant parts. New York: Academic Press.

BothA, J. 2001. Perceptions of avallability and values of medicinal plants traded on the western boundary of the Kruger National Park, South Africa. MSc dissertation. Unıversity of the Witwatersrand, Johannesburg.

Botha, J., E.T.F. WitkoWski \& C.M. Shackleton. 2002. A comparison of anthropogenic and elephant disturbance on Acacia xanthophloea (fever tree) populations in the Lowveld, South Africa. Koedoe 45(1): 9-18.
Botha, J., E.T.F. WitkoWSKI \& C.M. Shacki EION. 2004. The impact of commercial harvestıng on Warburgıa salutarıs ('pepper-bark tree') in Mpumalanga, South Africa. Blodiversity and Conservation 13: 1675-1698.

CARR, J.D. 1994. The propagation and cultivation of indigenous trees and shrubs on the highveld. Sandton Nature Conservation Society and Tree Society.

CLnNingham, A.B. 1988. An investigation of the herbal medicine trade in Natal/KwaZulu. Pietermaritzburg: Institute of Natural Resources. (Investıgational Report No 29)

CLnNingham, A.B. 2001. Applied ethnobotany people, wild plant use and conservation London: Earthscan Publications.

Geldenhtys, C.J. 2004. Meetıng the demand for Ocotea bullata bark. Pp. 517 - 550. In: Lawes, M.J., H.A.C. Eeley, C.M. Shackleton \& B.G.S. Geach (eds.). Indigenous forests and woodlands in South Africa people, policy and practice. Pietermaritzburg: L'niversity of Natal Press.

Grace, O.M., H.D.V Prendergast, J. Van Siaden \& A.K. JAGER. 2002. The status of bark in South African traditional health care. South African Journal of Botany 68: 21-30.

Grant, R. \& V. Thomas. 1997. Sappl tree spotting Lowveld Johannesburg. Jacana.

Grant, R. \& V. Thomas. 1998. Sappl tree spotting KwaZulu-Natal Johannesburg: Jacana.

Grant, R. \& V. Thomas. 2000. Sappl tree spotting Bushveld Johannesburg: Jacana.

Hankey, A. \& M. Siern. 2002. Acacla xanthophloea Benth. (http://www.plantzafrica.com/plantab/ acaciaxanth.htm)

Immelman, W.F.E., C.L. Wichi \& D.P. Ackerman. 1973. Our green heritage The South African book of trees Cape Town: Tafelberg.

JINIKKA, L. 1994. Survey of English macroscopic bark termınology. IAWA Journal 15(1): 3-45.

Mande R, M., J. Mander, N. Crouch, S. Mckean \& G. NICHOLS. 1995. Catchment action growing and knowing muth plants. Howick: Share-Net.

Palgrave, K.C. 1977. Trees of southern Africa. Cape Town: Strulk.

PoOL.EY, E.S. 1993. The complete field guide to trees of Natal, Zululand \& Transkel. Natal Flora Publications Trust.

Schmidt, E., M. Lötter \& W. McClel.and. Trees and shrubs of Mpumalanga and Kruger National Park. Johannesburg: Jacana.

ScOTT-SHAw, R. 1999. Rare and threatened plants of Kwazulu-Natal and neighbouring regions Pietermaritzburg: KwaZulu-Natal Nature Conservation Service.

TLrner, S. 2003. Rhus chirindensis Baker f. http://www.plantzafrica.com/plantqrs/rhus chırınd.htm 
VAN WYK, P. 1974. Trees of the Kruger National Park. Volume II. Cape Town: Purnel.

VAN WYK, G.F., D.A. EVERARD, J.J. MIDGIFY \& I.G. GORDON. 1996. Classification and dynamics of southern African subtropical coastal lowland forest. South African Journal of Botany 62(3): 133-142.

VAN WYK, B. \& P. vaN WYK. 1997. Field guide to trees of southern Africa Cape Town: Struk.

VAN WYK, B.-E., B. VAN OL'DTSHOORN \& N. GERICKE. 1997. Medicinal plants of southern Africa. Pretoria: Briza Publications.

Venter, F. \& J.-A. Venier. 1996. Making the most of indigenous trees. Pretoria: Briza Publications.

WILLIAMS, V.L. 2003. Hawkers of health: an invest1gation of the Faraday Street traditional medicine market in Johannesburg, Gauteng. Plant Ecology and Conservation Series No 15 (Report to Gauteng Directorate of Nature Conservation. DACEL). Unıversity of the Witwatersrand, Johannesburg, South Africa.

Williams, V.L. 2004. Trade and socio-economic value of forest and woodland resources withın the medicinal plant market in Johannesburg. Pp. 439 - 472. In: LAWES, M.J., H.A.C. EELEY, C.M. SHACKLFTON \& B.G.S. GeACH (eds). Indigenous forests and woodlands in South Africa people. policy and practice P1etermaritzburg: University of Natal Press.

Williams, V.L., K. BalKWILL \& E.T.F. WiTKOWSKI. 2000. Unravelling the commercial market for medicinal plants and plant parts on the Witwatersrand, South Africa. Economic Botany 54: 310-327. 